\title{
Medico-legal Issues Surrounding Medical Countermeasures Used in the Gulf War - Part 2
}

\author{
S N Galbraith
}

\begin{abstract}
When the multinational force deployed to the Gulf after Iraq's invasion of Kuwait in 1990, military intelligence assessed the Iraqis as possessing and being capable of using weapons of mass destruction. There was judged to be a real threat that chemical weapons, especially nerve agents and certain biological weapons would be used. Coalition countries attempted to reduce the effects by the use of medical countermeasures. Since the Gulf conflict a series of medico legal problems from this policy have arisen, some of which have formed the basis of claims against MOD. In the last article I reviewed consent to treatment in a military operational context and looked at potential clinical negligence issues. In this article I shall look at relevant employment law and review how medicine regulatory provision applies to medical countermeasures.
\end{abstract}

\section{COULD THE MINISTRY OF DEFENCE BE REGARDED AS A NEGLIGENT EMPLOYER?}

\section{Introduction}

We established in the last article the position regarding section 10 of the Crown Proceedings Act 1987. The Secretary of State could have made an order reviving s10 for the purposes of the Gulf war and have restricted the operation of s10 to certain specified areas in the Middle East or to certain specified activities. However, no order was made under s2 of the 1987 Act(1). Hence, in principle, there is no legal bar to a serviceman pursuing legal action in tort either in common law or a breach of statutory duty.

The employer owes all his usual duties to the employee; numerous statutes impose duties on employers in relation to employees.

Dr S N Galbraith

MA LLM MB BChir MRCGP

Consultant and Head of Department Army

Medico Legal

Army Medical

Directorate (Medico

Legal), 45 Millbank,

London SW1P 4RJ
Many of these are concerned with safety at work and the need to maintain a healthy work environment. Within the field of conflict itself there may be no duty of care. I looked at the case of Mulcahy (2) and how it may affect a medical negligence action in the last article. In this article I shall consider how broadly Mulcahy may be interpreted with regard to actions against the employer. Firstly I shall consider an overview of employment law as it might affect MOD as an employer providing medical countermeasures in the Gulf conflict.

\section{Common Law Duties}

Many of the duties an employer owes to his employees are found within the body of case law. As in medical negligence the claimant has to show that a duty of care was owed, there was a breach in that duty and as a direct result damage ensued.

Duty to employ competent staff: employers are considered responsible for engaging staff who are competent to undertake the tasks assigned. In Hudson(3) the employer was held liable for an employee's prank in which a fellow worker was injured.

Duty to provide proper plant and equipment: there is a duty on an employer to ensure that equipment provided is safe and properly maintained. Once properly trained to use the equipment, employers cannot be held responsible if their employees don't make proper use of it. In Parkinson $v$ Lyle Shipping(4) an employee was injured lighting a burner. He had received proper instruction in how to do so but chose to ignore it; the employer was held not liable.

Duty to provide a safe work place: employers have a common law duty to ensure that the work place is safe. This might even apply if the employee is working away from the employer's premises. It would depend on the situation and whether it was reasonable that the employer should do so. As a matter of common sense it would be impossible to inspect every place where workers could be sent. In Wilson v Tyneside Window Cleaning Company(5) it was held that the employer had done all that was reasonable to ensure the safety of an employee injured whilst out cleaning windows.

Duty to Provide Safe Work Systems: it very much depends on the circumstances whether a special system of work should be devised. It will depend to some extent what else happens within the industry; however the law will not condone dangerous work practices simply on the grounds that they are universal within the industry. In Re Herald of Free Enterprise(6), although it was standard practice within the industry to leave one of the ships doors open, it was still condemned as dangerous.

Duty to ensure health and safety: there is a 
common law duty to ensure the health and safety of employees and indeed if a provision is made in an employment contract that would compromise this or the other common law provisions then it would be regarded as unlawful.

\section{Breach of Statutory duty}

This is a very complex area and depends on the plaintiff showing: that the statute concerned intended to create a civil liability; that the statutory duty was owed to the individual plaintiff; that a duty was imposed on the defendent; that there was a breach of that duty and that the duty was of a type the act intended to cover.

Arguably the most important statute in this context is the Health and Safety at Work Act 1974. The complicating factor with this, as most other statues in the employment law field, is that its main objective is criminal rather than civil liability. However, secondary legislation promulgated under the Act specifically the Management of Health and Safety at Work Regulations(7) do so. Since the Gulf War the EC Framework Directive on Health and Safety is being implemented by regulations which state that they do give rise to civil actions.

\section{Did Common Law Duties of the Employer and Breach of Statutory Duty Apply to MOD in the Gulf War?}

I looked at the case of Mulcahy in Part 1; this is the key case on duty of care in a war or war like situation. It was held, as 'a matter of common sense and policy'(8), it would neither be fair, just, or reasonable to impose on a soldier (and of course vicariously as the employer on MOD) a duty of care to a fellow soldier during war or war like operations; even if there was proximity between the parties and forseeability. This would protect the employer against a legal action in common law or breach of statutory duty for an action or omission in the Gulf theatre of operations during the conflict.

A likely area of weakness for the employer concerns the months after the conflict when a massive clear up operation was in force and there were multiple environmental hazards. Whilst it may be in accordance with public policy that during the heat of battle no duty of care is owed, despite the two elements of proximity and forseeability being shown, during the clear up operation this would not be a credible defence.

During the air and ground war NAPS tablets were taken on orders based on a threat assessment. They were not taken after cessation of hostilities and no further vaccinations were given after the onset of the ground war. Prior to deployment it would be well nigh impossible for MOD to argue a Mulcahy defence as the plaintiff would not be in a 'war zone....taking part in war or war like operations...'(9). After the cease fire it would be difficult to argue, even on the broadest interpretations, that Mulcahy would hold; both common law duties, discussed above, and statutory provisions would again come into force. Probably the most important common law duty would be to provide a safe system of work and to ensure the health and welfare of employees. The most important statutory duties would be those found within the Workplace (Health and Safety at Work) regulations and the Personal Protective equipment at Work regulations (10).

There is some evidence that people who have taken NAPS may be sensitised to the organophosphorous insecticide and hence more likely to suffer from organophosphorous poisoning than if they had not taken the tablets. If this had been known at the time of the Gulf War the employer would, in effect, have an enhanced duty of care on the eggshell principle(11). If he knows an employee is more vulnerable than the typical employee then his duty to ensure the health and safety of the employee is enhanced.

\section{Medicines Regulatory Issues}

Until the early years of this century there was little regulation to control the prescription, usage and distribution of medicines. Early attempts to introduce some form of control included the Venereal Diseases Act 1917(12), and for biological substances, the Therapeutic Substances Act 1925(13). The Pharmacy and Medicines Act 1941 prohibited advertising of medicines for certain conditions and required patent medicines to be labelled with details of their composition.

In the wake of the thalidomide disaster in 1962 a voluntary scheme to control safety was introduced and the Committee on Safety of Drugs set up. Although voluntary all the major manufacturers complied with it. Finally a white paper was published in 1967 preceding the Medicines Act 1968 which received Royal Assent on 25 October 1968, replacing the various piecemeal statutes which had arisen in earlier years. The Medicines Act is an enabling Act in that it lays down general policies to be followed and leaves the detailed implementation to be made by statutory instrument (of which about two hundred have been made).

\section{Summary of Medicines Act 1968 Provisions}

The Act aims to control the safety, quality and efficacy of products in several ways. A product licence is required by the person responsible for its composition; there is control over the type of container used; tracing provisions using batch numbers to identify defective products; promotion and advertising of medicinal products.

Further changes occurred due to the UK 
joining the EC, including directives aiming to harmonise the laws relating to proprietary medicinal products(14). Other directives cover testing for analytical, pharmacotoxicological and clinical aspects(15). A later directive after the Gulf conflict brought in the necessity for a wholesale dealer's licence(16). All these EC Directives were embodied into UK law by statutory instrument, adding to the 1968 Act.

Once the detailed bureaucracy subsequent to the Medicines Act was established, it was inevitable that the whole registration process became inordinately risk averse. Nobody wanted another thalidomide; in the context of pharmaceuticals, the regulator has little or nothing to lose by refusing, or at least delaying, the grant of a licence(17).

\section{Licensing of Medical Countermeasures Used in the Gulf War: Overview}

A number of the medical countermeasures used in the Gulf War were unlicensed in the $\mathrm{UK}$ at the time. The MOD's position is that in 'each case the decision to use an unlicensed product reflected the need to protect British troops against a specific threat in the absence of an appropriate UK licensed alternative'(18).

Anthrax vaccine: the Centre for Applied Microbiology and Research (CAMR) at Porton Down has produced an anthrax vaccine since 1956. It has been licensed under the Medicines Control Agency, to the Secretary of State for Health Product Licence number 1511/0037 since 1979 for the protection of veterinary, laboratory and 'hair and hide' workers. The batches intended for procurement by MOD (batch numbers 337 to 351 were tested for compliance. The results from one test on a single batch was not satisfactory and that batch was withheld by CAMR(19).

Pertussis vaccine: There was considerable concern at the time of the Gulf that the anthrax vaccine may not be effective against an aerosol challenge or against particularly virulent strains and about the time required to build up adequate levels of immunity . Pertussis was used as an adjuvant vaccine as there was evidence that given simultaneously with anthrax vaccine then both the effectiveness of the anthrax vaccine would be enhanced and time to adequate immunity speeded up.

In 1990 a UK licensed pertussis vaccine was produced by Wellcome Research Laboratories under product licence $0003 / 1538$. The vaccine is not recommended for use in adults and the Medicines Control Agency has recently advised the MOD that it was not licensed for this purpose. Insufficient quantities could be procured to complete the courses for troops deployed to the Gulf and further supplies were procured from a
French manufacturer Merieux. They had sufficient stock available to supply a pertussis vaccine, which was not licensed in the UK but was in France, for delivery early in 1991. The vaccines, under the trade name IMOVAX, underwent toxicity testing after purchase at the National Institute for Biological Standards and Control (NIBSC) on the recommendation of the DOH. Test results showed the batches to be within specifications.

Plague Vaccine: The clinical course is inhalation by the aerosol route followed by an overwhelming lung infection after 2-3 days and death. The assessment that Iraq probably had plague is well established. There were two types of vaccine available in 1990: dead cell vaccine and live attenuated vaccine. The main source of dead cell vaccine was Cutter Biological, an American firm which produced a plague vaccine regularly used by US troops on some overseas deployments. At the time there was no data on the protection this vaccine would afford against an overwhelming inhalation of plague. Live vaccines, known to be more effective, were briefly considered. However the side effect profile including risk of liver abscesses and the fact they were not licensed in any western country made them unacceptable.

The US Food and Drug Administration (FDA) licensed the plague vaccine produced by Cutter Biological. Cutter Biological's licence number was no. 8 in the US and no. 24 in Canada. (In the US licence numbers refer to the firm producing the drug rather than to the licensed drugs themselves). In 1990 the US Department of Defence held a large stock of the Cutter plague vaccine. By agreement MOD made a priority acquisition in January 1991. The Cutter plague vaccine was not licensed in the UK. However, US Food and Drug Administration release letters were available for the relevant lot numbers. Samples of these batch numbers had been obtained in advance for testing by NIBSC (National Institute for Biological Standards and Control) who advised they complied with quality specifications.

Nerve Agent Pre treatment Set (NAPS): The primary defence for British troops against nerve agent poisoning during the Gulf war was specialised protective clothing worn with a respirator. However, given the very rapid onset of nerve agent poisoning and lethality additional protection was provided in the form of NAPS (pyridostigmine bromide $30 \mathrm{mg})$.

Work by MOD to obtain a Medicines Act product licence for NAPS began in July 1980. There were a series of delays including a change of supplier. It was not until August 1993, well after the Gulf War, that the licensing procedure was completed. NAPS is licensed by the Medicines Control Agency to the MOD for pre treatment of service 
personnel at risk from poisoning by Organophosphorous cholinesterase inhibitor. The product licence, number 04537/0003 was due to expire in 1998.

Post CW Attack Combopen: Immediate post attack treatment is by autoinjector containing: atropine, pralidoxine and avizafone known as the combopen. The Medicines Control Agency licensed Combopens to the MOD in 1996 under product license number 04537/0004. Prior to this the product was not licensed. However, if the individual or his colleagues needed to use the combopen after a CW attack operationally the situation would be extremely grim and the Mulcahy(20) defence would apply.

Biological Agent Treatment Set (BATS): In parallel with the prophylactic measures aimed at combating anthrax and plague, steps were also taken to provide a supplementary post attack treatment, which would provide further protection in support of the anthrax and plague vaccines. The antibiotic in BATS was doxycycline, a widely used antibiotic fully licensed in UK. The order to commence taking BATS would have been operational after a BW attack. However, as the attack would be in the field of battle whilst engaging the enemy no duty of care would be owed by MOD re Mulcahy(21)

\section{What About Liability?}

Prophylactic medicines in general and vaccines in particular are medicinal products for the purposes of the Medicines $\operatorname{Act}(22)$. Certain medical countermeasures, as outlined above, were used during the Gulf War without the appropriate licence cover under the Act. Breaches of this nature could potentially result in liability in respect of the criminal law. Whether breach of the licensing provisions of the 1968 Act could also give rise to an action for breach of a statutory duty is more complex. There are no express provisions conferring civil liability for such breaches, it would be difficult to argue that parliament intended to confer civil liability for such breaches. I shall look at possible action for breach of statutory duty later in this chapter. A more obvious challenge may be a negligence action, with the licensing scheme irregularities being taken as indicative of a failure in standard of care.

The courts may see parallels between the standard of care expected of the MOD when conducting a vaccination programme, and the standard of care expected of the Department of Health when conducting a treatment programme. The DOH lost a High Court action in 1995 in relation to the conduct of a human growth hormone treatment programme. On the basis of this judgement one could argue that the MOD had a duty '....to take all reasonably practicable steps to minimise the dangers and side effects.......to discharge this duty, constant alert and enquiring evaluation of the......programme is required'(23).

Morland $\mathrm{J}$ also criticised the $\mathrm{DOH}$ for failures to pass on warnings about the safety of the treatment to those responsible for the safety of the treatment programme and the clinicians actually treating the patients. Although this case did not advance the body of case law, hence unreported, it reminded people of the standards of care expected of government; indeed it pitched these standards high.

\section{Was the MOD actually bound by the Medicines Act?}

It is a general rule that the Crown is not bound by statute unless it is expressly bound or bound by necessary implication. Section 133(3) of the 1968 Act states: '......No exemption conferred by or under any provision of this Act shall be construed as derogating from any exemption or immunity of the Crown...'

This principle was considered by the House of Lords in an MOD context in Lord Advocate v Dumbarton DC(24). The court again applied the principle that the crown is not bound by statute unless it is expressly so, or is so by implication. The Dumbarton case is also authority for the proposition that legislation must either bind the crown generally or not at all.

Until 1 April 1991, when NHS hospitals lost their Crown Immunity, they were apparently not considered liable to the licensing provisions of the 1968 Act. The position pre- 1991 was consistent with the approach taken in an earlier case about the NHS's powers to make and use patented drugs without paying the patent holder for that privilege(25). The Pfizer case has been taken to apply to cases where an Act is wholly silent about the position of Crown servants because of the general rule that the Crown is not bound by statute, unless it is expressly bound or bound by necessary implication. It is therefore difficult to see how hospital services could not be bound by certain legislation because of crown immunity, but MOD could be bound.

It is arguable that the licensing provisions of the Medicines Act 1968 do not bind MOD. The argument against this is based on EC law. Where the provisions of the $1968 \mathrm{Act}$ and regulations made under it implement EC obligations those obligations will bind the Crown. It is likely that the Crown would be bound in such cases i.e. the state is bound by EC law and the armed services are in essence an arm of the state. To complicate matters further, Article 112.1(b) of the Treaty of Rome makes it clear that single market measures do not apply to products intended for 'specifically military purposes'. It is also implicit in article 224 of the Treaty 
that member states are entitled to take measures which distort the internal market 'in the event of war...or serious international tension causing the threat of war....'

The actual extent of these treaty provisions is not clear. It may be extremely difficult to argue that medicinal products were specifically for military purposes. I suppose it actually depends upon how a military purpose is defined. Article 224 may be a more creditable defence. Could it be applied only to a country preparing for war or could it also apply to measures relating to the armed services permanent state of readiness for action? If the latter were to apply then it could probably be used as a defence much of the time, and would certainly be against the spirit of the Treaty if not the letter.

Since the Gulf War there have been enormous changes to domestic medicines law, essentially as a result of the progressive introduction of EC measures relating to medicines control. Some of these measures have been implemented in 1968 Act regulations, or as amendments to the 1968 Act; others have been implemented in European Communities Act. The most important set of ECA regulations in this parallel EC derived scheme are the Medicines for Human Use (Marketing Authorisations etc.) Regulations 1994(26). In EC law medicinal products placed in the market within the EC must have a marketing authorisation(27), and must have been produced by someone with a manufacturers' licence(28). Also post Gulf, wholesale distribution of the product must have been done by someone with a wholesale dealers licence(29). In fact at least one wholesale dealer's licence has in fact been given to the MOD for the Defence Medical Depot at Ludgershall near Andover(30).

\section{Can the MOD manufacture products without the necessary licences?}

I have discussed how the anthrax vaccine had been manufactured for many years by CAMR and was licensed for use in the leather and associated industries. An MOD establishment manufacturing medicinal products may not need a manufacturer's licence under the Medicines Act 1968 because of Crown Immunity. It might however, need one under EC law(31) this again raises the question of a possible defence under Article 224. If the product would only be used in the event of war then the argument for saying a manufacturers licence was not required would be better than, for example, vaccines that were needed for a routine posting to a tropical country which was neither at nor threatened by war. This would be consistent with other areas of policy and law in that the more threatening the military situation the less justified individual soldiers would be in standing on their rights.

\section{Breach of Statutory Duty}

There are no express provisions resulting in civil liability for breaches of the 1968 Act. However, breach of statutory duty is an important area of tort, especially in relation to employer's liability. The first question is was the statute concerned intended to create a civil liability? It may be difficult to argue that the intention of parliament was to confer civil liability for such breaches. However, such breaches could be used as evidence of an inadequate standard of care in a negligence action. Indeed the fact that MOD arranged licensing of some such products pre Gulf, anthrax vaccine for example, would seem to indicate it accepted licences should be obtained. The fact that licences have been obtained post Gulf, in particular for NAPS, would appear to confirm this viewpoint.

When considering whether the statute was intended to create civil liability the courts look at the intention of parliament. Generally if the act was intended primarily for the general benefit of the community rather than individuals, it will not give rise to an action in tort(32 33). If the statute creates a duty, but no penalty, the courts will normally find that cause of action for breach statutory duty in tort exists. However, if the statute provides a penalty then it is not normally held to give rise to an action for breach of statutory duty(34). The more precise the wording of the statute the more likely that breach will give rise to civil liability(35). In the case of the Medicines Act, assuming that it does bind the Crown, it provides general provisions applying to the whole community, does not provide a named penalty and is broadly rather than specifically worded. It is not clear (if the Act does indeed bind the Crown), whether any breach of the licensing provisions could give rise to a breach of statutory duty.

\section{Conclusions}

I have established that common law and statutory duties normally owed by an employer to an employee are in effect suspended during war or warlike conditions. There may well be successful claims, especially involving the period after the Gulf War when the clear up operation continued. These should not involve the issue of medical countermeasures except, possibly, the enhanced effect of certain OPs and NAPS. However, even here it would be difficult to show causation, since the NAPS tablets were no longer taken at this stage and are not a medication which persists in the body for a long period after taking it. For an individual who served throughout the conflict and in the clear up operation, difficulties would arise in trying to apportion any harm occurring between the actual conflict (when 
battle conditions applied), and the clean up operation, (when they did not). It is ironic that if no medical countermeasures had been taken by the MOD prior to the GulfWar, and BW or CW weapons had been used, an employer negligence action could be brought on the grounds that adequate measures had not been taken to protect the troops.

I have established that there were medicines regulatory irregularities pertaining to the various anti $\mathrm{BW}$ and anti CW medications used by the armed forces with particular reference to the Gulf conflict. It may be possible to claim exemption from the provisions of the Medicines Act 1968 on the grounds that the act does not specifically bind the Crown. However, regulations produced as a result of EC directives would have to be adhered to by the armed services, since they are binding upon the crown, the armed services being an arm thereof.

There may be a defence to the various irregularities on the grounds of Articles 223 and 224 of the Treaty of Rome. Even if this were the case the burden of proof could well be on the British government to show that particular measures did not apply, rather than upon the European Community to justify applying the measures to the armed forces.

The MOD may claim that although it accepts that EC directives would apply to it, as an arm of the state, in normal peace time conditions, in emergencies it had to do whatever was necessary and would try to argue that it was exempted. This would be consistent with the common law position with regard to duty of care in war like conditions and a possible modification of the law of consent in such a situation. Should the courts accept that the Act does bind the Crown, the next stage would be to address whether any breach of the Act gives rise to an action for breach of statutory duty, or whether any breach would simply add weight to the plaintiff's argument in a negligence action.

\section{References}

1 Crown Proceedings Act 1987 s2: makes provision in time of war or war like activity for a certificate to be signed by the Secretary for Defence to re-enact crown Immunity for the period of the conflict. There is provision to restrict any order to particular geographical areas or activities.

2 Mulcahy v Ministry of Defence [1996] All ER 758

3 Hudson v Ridge Manufacturing Co Ltd [1957] 2QB 348

4 Parkinson v Lyle Shipping [1964] 2 Lloyds Rep 79

5 Wilson $\mathrm{v}$ Tyneside Window Cleaning Company [1958] 2QB 110

6 Re Herald of Free Enterprise (1989) The Independent 5 May

7 The Management of Health and Safety at Work Regulations Pub. HSE

8 Mulcahy v MOD [1996] 2 All ER 771

9 Mulcahy v MOD [1996] 2 All ER 756

10 The Management of Health and Safety at Work Regulations HSE

11 The defendent must take the plaintiff as he finds him

12 Veneral Diseases Act 1917 prohibited for the first time the sale and advertising of remedies for these diseases and the giving of advice regarding treatment or prevention except by medical practitioners

13 Therapeutic Substances Act 1925 introduced regulation of the manufacture and import of biological substances such as vaccines

14 EEC Directive 65/65 made provision that medicinal products placed in the market within the EC must have a marketing authorisation

15 EEC Directives $75 / 318$ and $75 / 319$

16 EC Directive 92/25

17 Teff H., 'Regulation under the Medicines Act 1968: A continuing prescription for Health' 47 Modern Law Review 310

18 'Background to the Use of Medical Counter measures to protect British Forces during the Gulf War' MOD report 28 Oct 97 www.mod.uk/gulf

19 'Background to the use of Medical Counter measures to protect British Forces during the Gulf War' MOD report 28 Oct 97 www.mod.uk/gulf

20 Mulcahy v MOD [1996] 2 All ER 756

21 Mulcahy v MOD [1996] 2 All ER 756

22 Medicines Act 1968 S 130

23 In the Matter of the CID Litigation $\mathrm{v}$ UKMRC and Secretary of State for Health Unreported

24 Lord Advocate v Dumbarton DC [1990] AC 580

25 Pfizer Corporation v Ministry of Health [1965] AC 512

26 SI 1994/3 144 Medicines for Human Use (Marketing Authorisations etc)

27 EEC Directive 65/65

28 EEC Directive $75 / 319$

29 EEC Directive 92/25

30 Licence no. WL/13527/001

31 OJ directive $75 / 319$

32 Lonro v Shell Petroleum [1982] AC 173

33 V Harpwood Principles of Tort Law 3rd Edn 1997 Cavendish Publishing 138

34 Cutler v Wandsworth Stadium [1949] AC 398

35 Monk v Warby [1935] All ER 373 